\title{
The Conflict between the Right to Religion and University Policies: Analysing a Policy Impact
}

\author{
Kimoga Joseph* \\ Lecturer in the College of Education and External Studies, Makerere University, P.O Box Kampala \\ *Corresponding author: kimogaj@yahoo.com
}

Received March 12, 2014; Revised March 26, 2014; Accepted April 02, 2014

\begin{abstract}
A country that has no state religion demands that government institutions shall not take on a particular religion as their main. Makerere University being a government institution is committed to recognising and treating equally all people from the religious divide. This article explores the relationship between University policies and students' right to religion. Focusing mainly on students wearing religious symbols, being availed physical places of worship, and having days of worship free of other academic programmes, the study explores a conflict between policies and the right to religion. It concludes that a positive attitude should be developed that religious symbols not only regulate students' behaviour but also identify them with their religions; doing justice to all in a pluralistic society demands that all or none is catered for by the university as regards providing a place of worship; and university and religious groups should make flexible programmes to enable students who fail to attend at some hours to do on other hours.
\end{abstract}

Keywords: policy, right, freedom, religion, religious identity

Cite This Article: Kimoga Joseph, "The Conflict between the Right to Religion and University Policies: Analysing a Policy Impact.” American Journal of Educational Research, vol. 2, no. 4 (2014): 225-232. doi: 10.12691/education-2-4-8.

\section{Introduction}

This article begins by discussing the legislative law basing mainly on the constitution of Uganda which speaks best to the issue of policies and students' right to freedom of religion in Makerere University. The article discusses the issue of religion and religious identity which are also pertinent issues to understand as I unravel this issue. Using the mixed approach methodology, the researcher collects data from a representative sample which aids in providing evidence and basis for the study discussion. The data is reported, interpreted and discussed resulting into conclusions drawn at the end of the paper.

\section{Legislation and Students' Rights and Freedom}

Makerere University being a public and government institution adheres to article 7 of the Constitution (1995) which provides that "Uganda shall not adopt a state religion". This requires Uganda government and her institutions to cater for all religions equally. However, Article 29, section (1), part (c) of the1995 Constitution of the Republic of Uganda states that, "Every person shall have the right to freedom to practice any religion and manifest such practice which shall include the right to belong to and participate in the practices of any religious body or organization in a manner consistent with this
Constitution”. Further in part (e) states that "Every person shall have the right to freedom of association which shall include the freedom to form and join associations, or unions, including trade unions, and political, and other civic organizations." This is reiterated in Article 37 that, "every person has a right as applicable, to belong to, enjoy, practise, profess, maintain and promote any culture, cultural institution, language, tradition, creed or religion in community with others."

In the light of the Constitution, Makerere University allows students to form associations which are registered with the Dean of Students' office after approval from the Students' Guild Minister of Constitutional Affairs, (Makerere University, 2012). The current students' associations include; academic, cultural, district/regional, religious, international, and alumni associations. The religious associations comprise of Makerere University seventh day Adventist Association, Makerere University Muslim Students Association, Nkurumah-Nsibirwa Christian Union, St Augustine Catholic community, etc. And in full knowledge and consideration of these rights, the University set policies to regulate their exercise. In one of the key manuals given in the welcome pack to new students and staff, the policy on Lectures and Examinations clearly articulates that, 'Makerere University is a secular institution,' '... all days in the week are considered working days; staff and students are expected to conduct or attend lectures and examinations at scheduled times and days' (Makerere University Regulations, 2012). The justification is that since the University has students and staff from various 
backgrounds, the University may not meet the interests of a particular group, particularly in the crucial areas of attendance of lectures and/or examinations. Students are therefore urged to respond to the academic work in their Academic Units even if they may take place on the respective days of worship. In 2003, this policy sparked off dissatisfaction when three Makerere seventh Day Adventist students filed a petition against Makerere University in the constitutional court. They sought a declaration under Article 137 of the constitution of Uganda that Makerere University policy and regulation of scheduling lectures, mandatory tests and examinations on the Sabbath day were inconsistent with and in contravention of Article 20, 29 (1) (c), 30 and 37 of the Constitution of the Republic of Uganda (1995). In the affidavit of the vice chancellor of Makerere, the rationale behind the policy was to avail access to education to more people. If the University were to observe the days of worship, there would be no day left for lectures and exams because of the many faiths in the country that have specified days for worship. The Students' petition was dismissed because it lacked merit and that it was raised in isolation of article 43 which provides that, "in the enjoyment of the rights and freedoms prescribed in this chapter no person shall prejudice the fundamental or other rights and freedoms of others or the public interest”.

Article 29, section (1), part (a) states that, "Every person shall have the right to freedom of speech and expression, which shall include ... freedom of thought, conscience and belief, freedom of practice of any religion, freedom to assemble." Freedom of expression is a civil right of persons. The freedom to express one's opinion includes such expression in different fora such as at a peaceful assembly, which may include religious assemblies. This resonates with Article 19 of the International Covenant on Civil and Political rights (ICCPR) which states that "everyone shall have the right to hold opinions without interference" and "everyone shall have the right to freedom of expression; this right shall include freedom to seek, receive and impart information and ideas of all kinds, regardless of frontiers, either orally, in writing or in print, in the form of art, or through any other media of his choice.” Therefore, Articles 29 and 37 of the constitution and Article 19 of ICCPR guarantee freedom of expression in word, deed/art, and freedom of peaceful assembly. The implication is that any person is free to express their religion in words, in dress or wearing any religious symbols and to congregate receive or impart information and knowledge about their religion. However, these rights and freedoms are not absolute. According to Article 43 of the constitution of the Republic of Uganda, they can be subjected to limitations in the protection of the rights of other persons and in public interest.

In this relation, Makerere University issued a policy statement on examinations that, '... students shall not wear attires that fully cover their face during examination' (ibid.). an example of the implementation of this policy was reported in the New Vision Newspaper (May 2012), that a female Muslim student in Makerere University was denied entry to the examination room because she was dressed in a manner inconsistent with the University policy. She had all her face covered. This sparked off hot reaction from the Muslim community at Makerere and a lot of heated debates in the public about the conduct of the examination invigilators and the Makerere policy.

These articulations and events of contest indicate serious conflict between policy and right to freedom of religion. Often parties subject to policies feel deprived of their constitutional right and freedom to religion. Therefore, these contentious issues of wearing religious symbols, having academic programmes on days of worship, and lacking space for religious assembly warrant investigation for better appreciation. Initially an understanding of religion and religious identity will help to guide the study.

\section{Religion}

Religion is about adhering to practices rendered to worshipping a god. This is not the same as believing in, putting faith in or trusting in e.g. a god. Wood and Hilton (2012) conceptualise religion as a 'shared belief system' based on principles, customs, practices and rites. While observing the principles, customs, practices and rites may imply subscribing to that religion, it may not necessarily mean so. Even a non-member may observe them. It is possible to be baptised according to the Catholic ritual or join the Catholic religion without necessarily embracing the Catholic spirituality; or getting circumcised according to the Muslim ritual and become a Muslim without necessarily embracing the Muslim spirituality. Spirituality could be to believe and behave in such a way that a transcendental power controls the believer. However, I hesitate to agree with Wood and Hilton's claim that this transcendental power is not necessarily belief in god but in any supernatural force or controller. A theist by default regards a supernatural controller to be a god.

Therefore, getting embedded into ways and/or traditions is not enough to identify one as a full member, but living the right spirituality of that faith tradition. Thus, although they all believe in the same Supernatural Being or God, Muslims, Catholics, seventh day Adventists, Orthodox, Protestants etc. each has a spiritual way rooted in their tradition of believing in God. This makes religion to be of many and diverse dimensions (Village, et al. 2011).

\section{Religious Identity}

Identity is about getting associated or affiliated to a certain person, group, entity, ideal or ideology. People by nature seek to be identified with something. This does not rule out the fact underlined by Mac and Ghaill, (1988, op cit. Rhamie et al., 2012) that the nature of identity sought for is not easily achieved; it is a process of refining the identity. However much people may strive to fit in predesigned identity categories, refining the identity goes through a process of formulation and re-formulation due to various identity images that present themselves to the person.

In infant stages, a person may easily identify themselves with a group through their elders, e.g. a child attending Sunday prayers at a Catholic church because parents do also attend. But at a later stage, a person begins to get free of acting because an elder does. One begins to 
act on their own and out of personal conviction. Regular performance of religious practices may become less but does not necessarily mean that one loses faith in their religious practices. That level opens one to more soul searching, seeking answers to spiritual questions.

This level coincides with young adulthood which is the age group for majority University students (Hadad and Schachter, 2011). There are challenges faced by students in managing religious identities. It is important to understand how identities are formed and transformed in Higher Education settings. It is as well important to understand how students negotiate and engage with diverse student populations. Some students identify themselves easily with their identity and others do not because of existing social attitudes (Rhamie et al. 2012). The social attitude may regard a group as minor and unimportant or major and important. This carries an impact on the members that subscribe to these groups. Therefore, in the process of building up identities, they are challenged by attitudes of others and the surrounding environment. Identities are then adjusted and rebuilt.

In any human being, a sense of belonging to a certain group, be it political, social, religious, etc. becomes stronger at the age of young adulthood. Being identified may not necessarily denote devotedness to the group/society identified with. In religious identification, for example, identified members remain relaxed in their behaviour not necessarily observing the religious obligations. As Hadad and Schachter (2011) observe, identification becomes more of a personalised matter than a group concern. This means that they rarely join the communal practices because these may be limiting to their freedom of operation in a way. In this case, one feels good to be identified with a group although not participating in religious practices. This, however, does not apply to all. Muslim young adult students on the contrary exhibit more interest in attending worship services (Small and Bowman, 2012). But even in the guise of not being overtly members of a particular religion, their religious background impacts on the way they perceive the world and reality around them. Banking on their religious background, they easily see forms of privileges or marginalisation in society done to them.

The perception of some people in the academia is that religion is a thing of the past and cherished by the unlearned, poor, uncivilised, and so on (Mackinnon, 1998; Willis, 2013). Religion seems to be a mention at the peripherals and religious issues are relegated to the unimportant realm. Ethical issues are explained from the social and academic point of view than from faith perspective. However, as Berger (1999, op. cit. ibid.) avers, despite what the academics and other atheists think, the world is as religious as ever, and in some places it is more serious than ever. This implies that even if people may not necessarily display their religiosity on the surface, deep inside they remain believers. Any deprivation of their right to freedom of religion that may occur in society may spark off overt or covert reaction.

According to Goldberg (2013) and Khakimova, et al. (2012), people's feeling of self-esteem easily connects to the esteem of the whole group to which they get identified with. Therefore, any success or good attained by the group to which one belongs boosts the esteem of the whole group as well as member self-esteem. Anything bad demoralises and breaks down the esteem of the group and the member as well. No wonder group members tend to attribute bad things to outside groups and good things to their groups to which they belong. This happens even when one is loosely identified with a group. They have to defend the group's image.

This explains why any group even if perceived minor, has to strive to keep their image high. Students' identification with minority faith groups may be a threat especially in situations where other faiths overwhelmingly overshadow populations of believers (McEntarfer, 2011). Such minority religious groups when deprived of their right of association can form disruptive actions to management or to the administration or entire institution (ibid).

\section{Methodology}

In order to explore the relationship between University policies and students' rights to freedom of religion, I carried out a field study in Makerere University where these policies exist and affect students. Since this focus concerns students, they became my key participants. In order to be more objective, I carried out a survey on 100 randomly selected students across the university. And to be able to obtain their detailed views on the same issues, I chose face to face interview with 17 of them. The student participants in this study were not to be regarded as isolated cases but understood in line of the University situation. Therefore, using the mixed methodology approach, I collected both quantitative and qualitative data, analysed and interpreted participants' voices in relation to University policies and its commitment to respecting students' right to freedom of religion.

\section{Data}

Commonly, some university students who subscribe to particular religions wear religious symbols which identify them with their beliefs. However, Makerere being a public institution, it is assumed not to go down well with those who do not subscribe to those religions. This assumption was subjected to a survey approach. I asked, by random selection, a cross section of 100 students in various university colleges and institutes. During the survey, I first asked the religious affiliation of every randomly selected student. The selection included 28 Catholics, 18 Protestants, 13 Muslims, 5 Seventh day Adventists, 28 Born again, 8 withheld their religious affiliations. Aware that not all religious provide religious symbols to their subscribers, the quest was not on who wears or does not wear, or has or has not, but on whether wearing religious symbols at campus, positively or negatively affects others who do not subscribe to the religion.

\begin{tabular}{|c|c|c|c|c|}
\hline Religion & $\begin{array}{c}\text { Number } \\
\text { asked }\end{array}$ & $\begin{array}{c}\text { Positive } \\
\text { effect }\end{array}$ & $\begin{array}{c}\text { Negative } \\
\text { effect }\end{array}$ & $\begin{array}{c}\text { Not } \\
\text { sure }\end{array}$ \\
\hline Catholics & 28 & 23 & 05 & -- \\
\hline Protestants & 18 & 05 & 10 & 03 \\
\hline Muslims & 13 & 12 & 01 & -- \\
\hline Adventist & 05 & 01 & 04 & -- \\
\hline $\begin{array}{c}\text { Born- } \\
\text { again }\end{array}$ & 28 & 08 & 15 & 05 \\
\hline Withheld & 08 & 05 & 03 & -- \\
\hline & $100 \%$ & $54 \%$ & $38 \%$ & $08 \%$ \\
\hline
\end{tabular}


This suggests that a greater number of students perceive wearing religious symbols as making a positive effect on other members who do not subscribe to that faith. Only $38 \%$, which is a significant number, acknowledged that it negatively affects other members of the faith. Just a minimal 8\% was not sure whether it does affect others or not. Significant to note is that Protestants and Born-again and Adventists have more numbers of those who feel that wearing religious symbols at campus affects others who do not subscribe to that faith. This could be due to the fact that their religions do not emphasise using such symbols. Catholics and Muslims, however, affirmed a positive effect maybe because their religions encourage using them.

Regarding places of religious assembly, although students have a God given right to faith as well as a Constitutional right to associate and to worship, I realised that despite this common knowledge, many religious groups lack designated places of worship at Campus. In reality, the Catholics, Protestants, and Muslims have designated places and others do not. In the survey approach, all Catholic, Protestant and Muslim students assented that the University has provided places of worship. It could be that they simply were knowledgeable of their respective places and not those of other religious groups. The Adventists and Born-again denied having places at the university where they could worship.

\begin{tabular}{|c|c|c|c|}
\hline Religion & Number asked & Yes & No \\
\hline Catholics & 28 & 28 & -- \\
\hline Protestants & 18 & 18 & -- \\
\hline Muslims & 13 & 13 & -- \\
\hline Seventh day Adventist & 05 & -- & 05 \\
\hline Born again & 28 & -- & 28 \\
\hline Withheld & 08 & 05 & 03 \\
\hline & $100 \%$ & $64 \%$ & $36 \%$ \\
\hline
\end{tabular}

On the issue of letting the days of worship free from academic programmes, it is important to note that in Uganda the known days of worship is Friday for Moslems, Saturday for Adventists, Sunday for Catholics and Protestants. This does not mean that these religious groups cannot meet on any other days of the week to worship or any other non-mentioned religious groups meeting on any of the above or other days in the week. However, the assumption is that the above three days should be left free from any university programmes to enable students attend their religious worship. The 100 students I asked in a quick survey gave various responses to the question of whether or not days of worship are left free from any academic programmes at Makerere.

\begin{tabular}{|c|c|c|c|}
\hline Religion & Number asked & Yes & No \\
\hline Catholics & 28 & 25 & 03 \\
\hline Protestants & 18 & 18 & -- \\
\hline Muslims & 13 & -- & 13 \\
\hline Adventists & 05 & -- & 05 \\
\hline Born again & 28 & 12 & 16 \\
\hline Withheld & 08 & -- & 08 \\
\hline & $100 \%$ & $55 \%$ & $45 \%$ \\
\hline
\end{tabular}

Most of the Catholic and Protestant students affirmed that the University lets the days of worship free from academic work because Sunday, being the last day of the week, tends to be less busy in academic programmes. Students are left free to relax and do other private activities. The Moslems and Adventists denied because Fridays and Saturdays are normal academic programme days according to the university arrangement.

Again using random selection, I subjected 17 students to interviews in order to seek their detailed opinions on the issues of wearing religious symbols at the university, having places of worship, and letting days of worship free from academic programmes. They were eight males and nine females (named A to Q). They were six Catholics, five Protestants, two Born-again, two Muslims, and two Adventists.

\begin{tabular}{|c|c|c|}
\hline Identifier & Gender & Religion \\
\hline A & Male & Catholic \\
\hline B & Male & Protestant \\
\hline C & Male & Catholic \\
\hline D & Female & Adventist \\
\hline E & Female & Muslim \\
\hline F & Female & Muslim \\
\hline G & Female & Protestant \\
\hline H & Female & Born-again \\
\hline I & Female & Protestant \\
\hline J & Female & Adventist \\
\hline K & Male & Catholic \\
\hline L & Male & Born-again \\
\hline M & Male & Catholic \\
\hline N & Male & Catholic \\
\hline O & Male & Protestant \\
\hline P & Female & Protestant \\
\hline Q & Female & Catholic \\
\hline
\end{tabular}

Apart from the gender quality, the selection of participants was random and not limited to religion or any other background. The gender quality was considered because of the assumption that gender perceptions may differ as regards policies and right to religious practices in the University. The key issues to question about were in order to solicit their views on how University treats students; wearing religious symbols/icons, as regards availing spaces of worship to them, and respecting their days of worship.

In relation to their views on students wearing religious symbols for example; rosary, religious medal, Hijab and so on at campus, student A acknowledged that, "it is good to wear religious symbols because they help one to know more about their religion." This view was shared by student B who added another value that, "for those who use them [religious symbols], I think they protect them in whatever they do." Student C accentuated that the benefit of wearing religious symbols is to remind the person of the religious values that one has to uphold. Nevertheless, student D asserted that, "a symbol is a sign of identity; therefore, there is no harm in wearing religious symbols to show ones religious identity." Student E said that, "it is normal and obvious act to wear religious icons". Student F confirmed that religious symbols help us to know and understand our religions better. "They help to regulate the behaviour of the bearers because they act as identity, which should not be betrayed." Other students H, K, J, I, $\mathrm{M}, \mathrm{N}, \mathrm{O}, \mathrm{P}$ and $\mathrm{Q}$ also supported the practice and expressed their views. Student $\mathrm{H}$ argued that, "students should wear religious symbols to enable them identify with their religions. This shows that the students are not ashamed of their religion." And student J added that, "it is a symbol of good faith". It is "an inherent right to belong to a religion and to show the belongingness in public. Therefore, wearing religious symbols is fine”, student $\mathrm{N}$ reflected, a belief that is evidenced by the constitution of Uganda as quoted by student $\mathrm{O}$, that, "every person shall have the right to freedom to practice any religion and manifest such practice ..." Student Q observed that, wearing religious symbols at campus "enables students to be respected according to their religious beliefs". This view was corroborated by student I that, "it is a good thing, 
for example, a rosary will remind Catholics of their commitment to God and caution their behaviour in the community." In other words, as Student M further asserted, "it is not bad wearing holy rosary, crucifix, Scapulars and others because they have been blessed by a priest; they put one in a pious behaviour at campus".

On the other hand, these symbols are perceived as making a negative effect or disliked by others. Student $G$ said that, "at the university, people should look uniform and only strengthen their faith by showing good example." In the same vein, student L stated that, I sincerely dislike seeing somebody wearing a Muslim cap, Hijab and covering the whole body at campus... I feel insecure seeing somebody covering the whole face especially in the era of terrorism.

Student C intimated that, "it should not be enforced on members of other religious groups and should be decently worn.” Student B also added that since the University is a public place, it should remain a place for academic work. "These symbols in a way propagate religious ideals, and thus should be discouraged from being used at the University which is a neutral place for students of all backgrounds." Student D underlined that,

There is a challenge of teaching the implications and benefits of the use of those symbols to non-members in order to appreciate such symbols. However, this at times leads into converting others (non-members) especially in the process of explaining to them the meaning of the symbols. Yet universities should not be places for converting others to religion.

On whether or not University should designate a place of worship for every religious group on campus, students, L, M, and G agreed that, "the university should designate places of worship" and K added that, "so long as that religious group is able to construct a structure to worship from." Student $\mathrm{H}$ also supported the idea and added that "these places help students to communicate better to their God”. This student, however, noted that, "there are vast religions; putting up a worship place for every religion may be quite expensive”. In the same vein, student I reflected that although it would be a right thing to do, "some religious groups are almost insignificant because of their small numbers like the Orthodox, and besides, it is not cost effective because at the end of the day, one may fail to register enough attendance in some places of worship.” Student O particularised Protestants, Catholics, Muslims, and Adventists as the only traditional groups that deserve places of worship. The student said that this is because "these groups are more formal and have liturgical procedures and practices which are more organised and well known than other religious groups.” On contrary, student $\mathrm{P}$ denied that, "it is not necessary because it might be costly but they should instead be given freedom to worship and allowing them to find space for worship." This denial was shared by student Q who said that, "the university should not provide places of worship because Uganda is a pluralistic society as far as religion is concerned. The university may not be able to cater for all these religions.” Catholic, Muslim and Protestant students acknowledged that they have places of worship designated by the University. On the contrary, student J said that,

Our religion has been a victim of lack of a place of worship in Makerere University. We all seem to be attached to a supernatural being, so the quest needs to be quenched by having a descent place designated.

This was substantiated by student $\mathrm{N}$ that, "since every person has the right to religion, every religion needs to be given a place of worship without discrimination. This is because the Born again groups and the traditionalists are almost not catered for." Another Adventist student added that, my religion was never given a place where we could gather to worship on Sabbath. We simply rent a hall that belongs to St. Augustine Catholic Chaplaincy. We have always requested for a place, but University management does not attend to our request.

The student's claim was corroborated by some Bornagain participants who ascertained that the University has neither designated any places of worship for other religions nor any chaplains to guide these students. Students who belong to these religions either go to places of worship outside the University or use lecture rooms when there are no lectures taking place. In this case the students choose among themselves leaders to lead them, or they solicit funds to support chaplains from outside the University. Student participants unanimously complained that University's failure to provide places of worship to some religions which are allowed to exist in the country is discriminatory. If the University is committed to treat all equally, then every religious denomination should be given a place where to gather for worship. In particular student A said that, no wonder Born-again students meet in free lecture rooms during time when lectures are still running in other rooms, and begin praying. Even if this may be irritating because they always sing to the top of their voices, they should not be blamed because they have to use the available opportunity of free space. Had they been given a particular place where they could gather, maybe we would overcome the disruptive singing.

In interviews with some students on the issue of whether university lets the days of worship free from academic programmes, I received various views. Student $\mathrm{G}$ said that, unfortunately the days are not respected days of worship. They tend to put exams and others programmes on weekends. This has affected many students, e.g. the Adventists who resist doing exams on Saturdays and they end up doing retakes. They should be given freedom to worship on their days.

Student B intimated that respecting days of worship is an obligation and a right to those that subscribe to the religion that worships on that day. Therefore, University should let these days free. He however, specified weekend (Saturday and Sunday) as the days referred to. He said that Fridays may not be free of academic work because he sees many Muslims who work on Friday provided they attend prayers. Therefore, he thinks Muslims are not obliged to abstain from work on Friday. On a similar note, Student D stated that, in Uganda today there is freedom of worship. To me everyone is free to worship on the day proper to their religion. That day gives meaning to them and there are rituals and practices some religions may require members that subscribe to them to perform. In our seventh day Adventist religion, we are asked to abstain from doing serious work on Sabbath of which academic is part. We should not freely mingle with non-members of our religion on Sabbath. If University insists on putting academic programmes on such days of worship, it deprives us of our right to freedom of worship. And if one 
rationalises that we are free to forego academic work for the sake of religious worship, again one has to appreciate that as students we are deprived of our constitutional right to education.

Students I, J, K, O, Q and $\mathrm{H}$ affirmed that university does not let days of worship free from academic programmes. They supported the practice because, "giving every religion a day of worship may leave none for teaching and learning." Student $\mathrm{N}$ added that, "since all religious interests can't be harmonised with academic programmes, students should choose what is more important at any given time.” To further the argument, student E insisted that letting days of worship free of academic work jeopardises academic progress. "There are many religions in Uganda. If every religion was to claim a day of worship, and each of them became a day of rest, when would we do academic work?” The student was certain that students can attend prayers any time of the day when academic programmes have ended. God understands the situation in which they are and cannot blame them for failure to attend services on that day. Her idea was shared by student $F$, who further stated that, letting some days of worship free of academic work is discriminatory to those whose days of worship are filled with academic programmes. The University should not allow such days because as students in this public institution we are all equal. No special favours should be granted to some at the expense of others. Those who wish to be free from academic work can choose to do so at their own cost.

On the contrary, Student A stated that, although the students' manual states that all days of the week are lecture days, the University tries to respect days of worship. Most of the lectures run from Monday to Friday. In rare cases, or for students who are on evening and weekend programmes, they are asked to attend lectures on weekend. Also during the time of exams, the programme may cover Saturday and Sunday. Although we have religious obligations, for example, as a Catholic I must attend Sunday mass, I can attend the lecture or exam and later go to mass in any nearby church.

Student C came out more strongly on University programmes and days of worship saying that, the University cannot be a successful academic place when it commits itself to observing days of worship for students. If one knows that s/he came to study in this public institution, then one has to abide by the time of the academic programmes. There are other universities founded by various religions in the country, I hope they observe days of worship. Students who wish to have days of worship let free from academic work can enrol in those universities.

\section{Interpretation}

It is everyone's constitutional right to belong to some creed or religion and to practise it. Chapter 4, article 29, number 1, part C of the constitution of Uganda (1995) affirms that all people have the right to belong to some creed or religious belief. Therefore, wearing religious symbols is everyone's right and identifies them with their religion. In the same line, as suggested by student $\mathrm{A}$, it is the prerogative of the staff to encourage students to wear these symbols. The professional ethics encourages educators to teach students to respect the religious views of other people even when they differ. Religious symbols show that students belong to diverse religious backgrounds and that they should respect each other. This is as well underlined by student F. Chapter 4, article 34, number 3 clearly states that it is illegal to discriminate against anybody on the basis of showing their religion. Therefore, wearing religious symbols should not be a cause for discrimination.

Wearing a religious symbol makes the bearer proud of their religion and the values attached to the symbols. Religious values shape a person's moral virtues which are necessary for proper conduct in society. Moral virtues e.g. tolerance, forgiveness, love are fostered especially when one wears these symbols. One will be keen not to falter or be caught doing a wrong thing when bearing a religious symbol else it demeans the religion they identify with. University as a social place needs people of balanced attitude towards others and their actions. As a person is gradually accepted for their identity, a balanced attitude is gradually formed. The variety of identities and attitudes, beliefs and values make a harmonious society that is liveable.

However, some student participants indicated that using religious symbols in multi-faith communities is like imposing ones religion on others who are non-members. In such public situation, there should be neutrality in dress, speech, action and members' religion should not affect others at all. As students B and D comment, Makerere as a public University should not be a place for overt or covert propagation of religious ideals and conversion of others. This seems to suggest that there should be a clear boundary between academic issues and religious issues in Makerere University if the right quality of education is to be passed to students. The latter should not interfere with the former at all.

Students expressed that, the fact that there is no single law that denies wearing religious symbols at campus, the University should positively appreciate the cause of 'freedom of worship' and help members adhere to that appreciation. This will help to make learners feel comfortable at the University that accommodates all. Religious symbols should be used to foster unity, love and respect for each other at the University. It is like saying, for example, that if a dove is used by a certain religion to symbolise peace, then all students regardless of their religious belongingness should strive for peace at the University. In this case, a religious symbol becomes a symbol for all. The identifying marks of religious symbols help to bring together students from various cultural, social, economic, political divide into a single person. The associations formed on this basis help to shape students into a better person.

While students of the Catholic, Protestant and Muslim religions acknowledged having places where they converge to worship, student D indicated that other religions have not been given any places for this cause. This creates commotion in the University when students have to find places where they could worship from. In addition, since they lack places for worship, they do not have chaplains as University staff to guide them. The above religions have chaplains as University staff and paid for their duties. The students' voices affirm that equal 
justice done to students of diverse religious belongingness is what they would wish for at Makerere University.

Nevertheless, students stated that although University allows them to worship, there is clear non-observation of the days of worship. Students B and D preferred days of worship to be left free from academic work so as to enable members attend services. However, Makerere University Regulations (2012) state, ' $\ldots$ all days in the week are considered working days; staff and students are expected to conduct or attend lectures and examinations at scheduled times and days'. Therefore, mentioning that University sets academic programmes e.g. lectures and examinations on days of worship shows a big conflict between the right to worship and the policy of running University programmes. Some students C and E, however, denied the view of setting aside days of worship free from academic work because these are many, and they could affect academic progress and the quality of education offered at the University. This implies that time spent on religious observations is a wastage for many students who do not subscribe to that religion and even some that may be members of the religion. And as student A suggested, those who wish to attend religious services should adjust and search for services that take place after academic programmes.

\section{Discussion}

The issues of wearing religious symbols, places of worship, and days of worship are contentious in Makerere University because they relate to profound element in human life, i.e. religious identity. As I discussed above, religion tends to provide achievable and non-achievable answers to people's deep quests. Lots of questions asked may not receive convincing answers from social, political or economic realms. These realms may instead widen the vacuum. People instead turn to religion as a provider of answers to their questions. This may be life-long to some and short lived to others. As a matter of fact, people harbour religious tendencies which may sometimes be brought to the fore to show their true identity. Among University age going students, these tendencies tend even to be covert as long as everything is fine, i.e. when their religious beliefs are not challenged by situations. However, any situations or traces of challenge and deprivation arouse feelings to defend their beliefs. This explains the reasons voiced by the student participants in this study.

Wearing religious symbols in public places like at Makerere University may seem provocative to some, propagating religious ideals to others, but it is mainly a sign of pride one attaches to their religion. One feels proud to be identified with a religion that gives meaning to them. The University that seeks to uphold people's religious values and beliefs should respect the worth that students attach to their religions. It is possible, for instance, that students may cheat in exams, and they have all tricks to do so. However, the policy articulation in the Makerere University Regulations (2012) that female Muslims must remove their hijabs before entering the examination room, may be intrusive to them and misdemeanour done to their religion. Therefore, University policies of this type inevitably clash with the students' right to religion. It is therefore important to consider that although the
University is public and does not adopt any religion as University religion, understanding and appreciating students' religious identity is paramount. There should be a better way of curbing the habit of cheating. If it persists, the University can recruit female Muslim staff to thoroughly check female Muslim students to ascertain that they carry no devices in their hijabs to examination rooms.

Designating places of worship is the mandate of the University. Since Makerere does not belong to any religion, it is committed to treating all religions equally. Now the question is whether Makerere should consider only those that are traditionally registered or even the new religions. Apart from the Protestants, Catholics and Muslims, there are many others; the seventh day Adventist, Orthodox, Pentecostals, etc. that have come up and do claim recognition. These all have students that subscribe to them as their faithful. If Makerere respects the religious affiliation of every student, it is proper that at least all registered religions are given provisions where students could gather to worship. Places of worship are where a person meets their God and vice versa in a special way. As Village, et al. (2011) and Wood and Hilton (2012) suggest, spiritual exercises benefit students a lot. They feel satisfied with their studies and the environment and many overcome academic stress and breakdown. And this cannot be everywhere on campus but in a designated place. I do not overlook the fact that it is not cost effective meeting the need of providing designated places to all. In this case, it may not help keeping a deaf ear on members of other religions who keep asking for places to worship. The way to go is doing justice to all by adopting an 'all or none' policy.

In addition, the University should recruit chaplains proper to the existing religions in the University who could lead students in services as well as assisting in spiritual counselling and nourishment. It appears unjust if public funds are used to facilitate chaplains of a few religions at the expense of other religions that are not catered for.

In relation to observing the days of worship, the University policy is clear that, '.. all days in the week are considered working days; staff and students are expected to conduct or attend lectures and examinations at scheduled times and days' (Makerere University Regulations, 2012). This, however, clashes with Article 29, section (1), part (c) states that "Every person shall have the right to freedom to practice any religion and manifest such practice which shall include the right to belong to and participate in the practices of any religious body or organization in a manner consistent with this Constitution" (Constitution of the Republic of Uganda, 1995). In fact there are religions that strictly prohibit their faithful from doing serious work on days of worship. And the University should not be a cause of temptation to students to fail in their religious principles. In the research, some students supported letting the days of worship free from academic programmes, and others did not. But since the university mission is to meet the academic excellence, relaxing the academic programmes may help students to attend to their spiritual exercises. This also calls for dialogue with religious groups to programme the exercises flexibly to help students attend those in hours not conflicting with some academic programmes. 


\section{Conclusion}

This article set out to study the relationship between Makerere University policies and students' right to religion particularly with regard to wearing religious symbols, availing physical spaces of worship, observing days of worship. Through carrying out qualitative and quantitative research the study has explored that there is a big conflict between the policies and the students' right to religion. This is a violation of students' right to religion by the University.

The study concludes that the practice of wearing religious symbols is done for the intention of showing their religious identity to the rest. This positive attitude should be encouraged by the university because it not only enables them to know more about their religion and propagate it, but also to regulate their behaviour.

Places of worship are where a person meets their God; but designating places of worship is an expensive venture for the university. However, doing justice to all in a pluralistic society demands that all or none is catered for as regards providing a place.

While some students asked for letting the days of worship free from academic work, others were not in favour. I order to keep the university mission as well as making students attend their spiritual exercises, flexibility is required. The university should allow flexible programmes on these specified days and ask religious groups also to provide flexible spiritual programmes to enable students who fail to attend at some hours to do on other hours.

\section{References}

[1] Goldberg, T. (2013). "It's in My Veins": Identity and Disciplinary Practice in Students' Discussions of a Historical Issue, Theory \& Research in Social Education, 41: 1, 33-64.

[2] Hadad, T. \& Schachter, E. (2011). 'Religious-lite': a phenomenon and its relevance to the debate on identity development and emerging adulthood, Journal of Youth Studies, 14: 8, 853-869.

[3] Human Rights Network for Journalists (2012). Freedom of expression in Uganda.

[4] Khakimova, L., Zhang, Y.B. \& Hall, J.A. (2012). Conflict Management Styles: The Role of Ethnic Identity and SelfConstrual among Young Male Arabs and Americans, Journal of Intercultural Communication Research, 41: 1, 37-57.

[5] Mackinnon, A. (1998). Educated doubt: women, religion and the challenge of higher education, c. 1870-1920 [1], Women's History Review, 7: 2, 241-259.

[6] Makerere University Regulations (2012). Approved by Council, May 2012. Makerere University Printery, Kampala.

[7] McEntarfer, H.K. (2011). "Not Going Away": Approaches Used by Students, Faculty, and Staff Members to Create Gay-Straight Alliances at Three Religiously Affiliated Universities, Journal of LGBT Youth, 8: 4, 309-331.

[8] Rhamie, J., Bhopal K. \& Bhatti, G. (2012). Stick to your own kind: Pupils' Experiences of Identity and Diversity in Secondary Schools, British Journal of Educational Studies, 60: 2, 171-191.

[9] Small, J.L. \& Bowman, N.A. (2012). Religious Affiliation and College Student Development: A Literature Review and Synthesis, Religion \& Education, 39: 1, 64-75.

[10] The Constitution of Uganda the Republic of Uganda (1995). Ministry of Justice and Constitutional Affairs, Kampala.

[11] Village, A., Francis, L.J. \& Brockett, A. (2011). Religious affect among adolescents in a multi-faith society: the role of personality and religious identity, Journal of Beliefs \& Values: Studies in Religion \& Education, 32: 3, 295-301.

[12] Willis, O. (2013). Religion and international development in the Canadian academic context, Canadian Journal of Development Studies/Revue canadienne d'études du développement, 34: 2, 275290.

[13] Wood, J.L. \& Hilton, A.A. (2012). Spirituality and Academic Success: Perceptions of African American Males in the Community College, Religion \& Education, 39: 1, $28-47$. 